\title{
EDUCATION FOR CHILD HEALTH WORKERS IN DEVELOPING REGIONS
}

\author{
D. B. Jelliffe, M.D., F.R.C.P., F.A.P.H.A. \\ (UNICEF Professor of Padiatrics E Child Health, Makerere Medical School, Kampala, Uganda.)
}

PafDiatrics, with its modern combined curative, preventive and social perspectives, and working in firm alliance with preventive medicine, is, or should be, one of the most important aspects of medical education in the technically developing regions of the tropics, including East Africa.

Reasons for this are numerical and qualitative, and also because a healthy childhood population represents the prime economic investment for the future.

\section{Problems of Child Health}

In Uganda $44 \%$ of the 6.5 million population are below 15 years of age. The estimated overall infant mortality rate (IMR) is 160 per thousand live births, with much higher figures certain in some areas. The eminently preventable one- to four-year mortality, so often due to multiple diseases, is not known, but is also high, being proportionately even more than the IMR, when compared with findings in Europe and North America. It can then be assessed that about $40 \%$ of the total mortality occurs in the under fiveyear-olds. In fact, as Cicely Williams has remarked epigrammatically, the principal problem of "tropical' medicine is childhood.

While the disease picture among children is not known with accuracy, an approximate idea can be gained from hospital admissions, and from attendances at out-patients, dispensaries and child welfare clinics, complemented by such field studies as the Community Child Health Surveys currently being carried out by the Department of Pædiatrics and Child Health and of Preventive Medicine among African peoples living in different ecological circumstances in East Africa, as, for example, the Bachiga of Kigezi (Jelliffe, Bennett, Stroud, Novotny, Karrach, Musoke and Jelliffe, I96r).

An example of the general hospital pattern of disease is given by an analysis of admissions to the Pædiatric Division at Mulago Hospital in 1959, which demonstrated that gastro-enteritis ( $18 \%$ ) and protein-calorie malnutrition* $(14 \%$ : kwashior-

*This term is preferred for this common and important spectrum of syndromes of malnutrition for reasons given elsewhere (Jelliffe, I959, I96 ra.). kor $10 \%$, nutritional marasmus $4 \%$ ) headed the list, followed by malaria, respiratory tract infections, severe anæmia (including hookworm disease and sickle-cell anæmia) and tuberculosis (Musoke, 196I). Of special interest was the top place of infective diarrhœal disease in young children, an uncommon condition ro years ago (Davies, 1955). This striking change is in main undoubtedly due to the spread of unnecessary bottle feeding among uneducated, less well-to-do African mothers in Buganda (Welbourn, 1958; Jelliffe, 196ra).

This picture, similar to that found in other technically developing tropical regions, contrasts greatly with the 'supra-pædiatrics' of the presentday Western world with its energies, quite correctly, directed towards behaviour problems, congenital anomalies and metabolic disorders, but would approximate closely to what would have been found in Europe and North America in the last century and earlier.

There are, in fact, four main groups of ' moulding' factors which influence the panorama of health and disease in childhood in different parts of the world: ( $\mathrm{r}$ ) socio-economic (including levels of public hygiene and of general education), (2) cultural, (3) genetic and (4) geographico-climatic (Jelliffe, 1957a). The commonness of such genetically transmitted conditions as sickle-cell anæmia will obviously influence the local disease pattern, as among the Baganda, $17 \%$ of whom are trait carriers; likewise the fact that geographicoclimatic circumstances permit the tsetse fly to breed will mean that trypanosomiasis may be a problem. However, the main determinants of present-day ' tropical' pædiatric problems are none of these, but are rather the result of poverty, defective systems of excreta disposal, squalid overcrowded housing, inadequate contaminated water supplies and lack of modern knowledge by parents (both in villages and increasingly in the "septic fringe' slums too often resulting from industrialization and urbanization).

The local culture pattern is also of the greatest significance as regards child health, especially customs during pregnancy and childbirth, methods of child rearing, food ideologies and indigenous 
concepts of disease (Jelliffe and Bennett, I960, I962). Harmful cultural attitudes may be traditional, as with the use of cow dung as a cord dressing or with dietary restrictions which prevent the young child from receiving protein actually available in the village (' cultural blocks') (Jelliffe, $1957 \mathrm{~b}$ ), or, in recent years, regrettably may represent newly-adopted harmful Western habits, such as the use of aerated drinks, over-milled flour, and especially unnecessary bottle feeding, all of which have disastrous effects on infant nutrition (Jelliffe, r955a, r96ra).

In addition, necessary rapport can best be established by health personnel knowing and, as far as practicable, respecting the local culture pattern, while health education, which is, in fact, the minor modification of a people's ways of living, can only be attempted seriously if present attitudes, beliefs and practices are known.

\section{Development of Child Health Services}

In Uganda, as elsewhere, the development of child health services has lagged from lack of appreciation of the magnitude of the problem and because of competing claims for very limited finance for other medical service activities, and also for other much needed social and economic developments, including schools, communications and food production.

It is, then, in this atmosphere of extremely restricted finance for staff, equipment, drugs, buildings and transport that child health services are having to develop. At the same time, there is the widespread paradox that, while most of the childhood disease that is seen is partly or completely preventable, past emphasis by medical planners and present popular (and political) enthusiasm is weighted in the direction of the more obvious, pragmatic benefits of curative services, especially hospitals. As a result of this, finance and staff become increasingly neutralized by their full-time preoccupation with 'finger in the dyke ' activities aimed at dealing with the flood of sick, so that little or no emphasis can be given to root-cause preventive measures.

\section{Principles of Training}

Trained staff at all levels is the primary need, but it is equally important that the education and training of all cadres engaged in child health work in developing tropical regions is always realistically related to the local ' facts of life ', both in the sense of the pattern of disease, indigenous culture, finance available (or lack of it), problems of communications and especially the need for rethinking the content of training in relation to the actual functions that will have to be performed by personnel in the particular country at its present stage of development. Basically, as Cicely Williaims (1958) remarks, the true need of develop countries is for pædiatric services with a broad outlook and with curative, preventive and social functions.

Training must, therefore, also be wide in perspective, embracing preventive, curative, social e्fd cultural aspects of child health, but with the theme of prevention, especially by means of he Th $^{\text {th }}$ education, dominant throughout. The functions and value of other types of medical and parramedical staff, and of other parallel endeavoürs related to the development of a healthier country, such as education, community development agriculture, will also have to be made apparentoto trainees.

A ' bifocal ' viewpoint must be given the studejnt in relation to methods he will be able to employ. Primarily, he must learn how to make use of simpte, rapid, practical, inexpensive methods, with minimum laboratory facilities, but which will bene्sit large numbers of patients. However, at the same time, the medical student will also have to be taught, at least in outline, about more recent and precise methods, and encouraged from the loggterm point of view to the hope that as facilifies improve so can his own practice become möre scientific.

What has been termed the ' interim philoso also requires note, and is based on the realifition that less well-trained personnel have to be tused temporarily pending the time, usually a matterof years or decades, before fully-trained staff slow become available in adequate numbers. The practical instruction of traditional village bilth attendants until enough qualified midwives haेve been trained may be quoted as a well-known example.

Adaptability is an essential feature in the planning of child health services anywhere, esperially in developing regions, and appreciation of this must influence the training of staff intended to nan these facilities. For example, the developmentiof exclusively preventive child health clinics as found in the Western world may be an impossibility i a tropical country, as these presuppose an efficient functioning liaison with easily available adequate hospital facilities nearby, which are not usually available (Cicely Williams, 1955); whổe, anyway, the majority of the child populationin many tropical regions may be sick or, at leşst, 'not well'.

\section{Categories of Trainee}

(I) Undergraduates

Students at Makerere Medical School come from all the East African territories, that is Uganda, Kenya, Tanganyika and Zanzibar. 


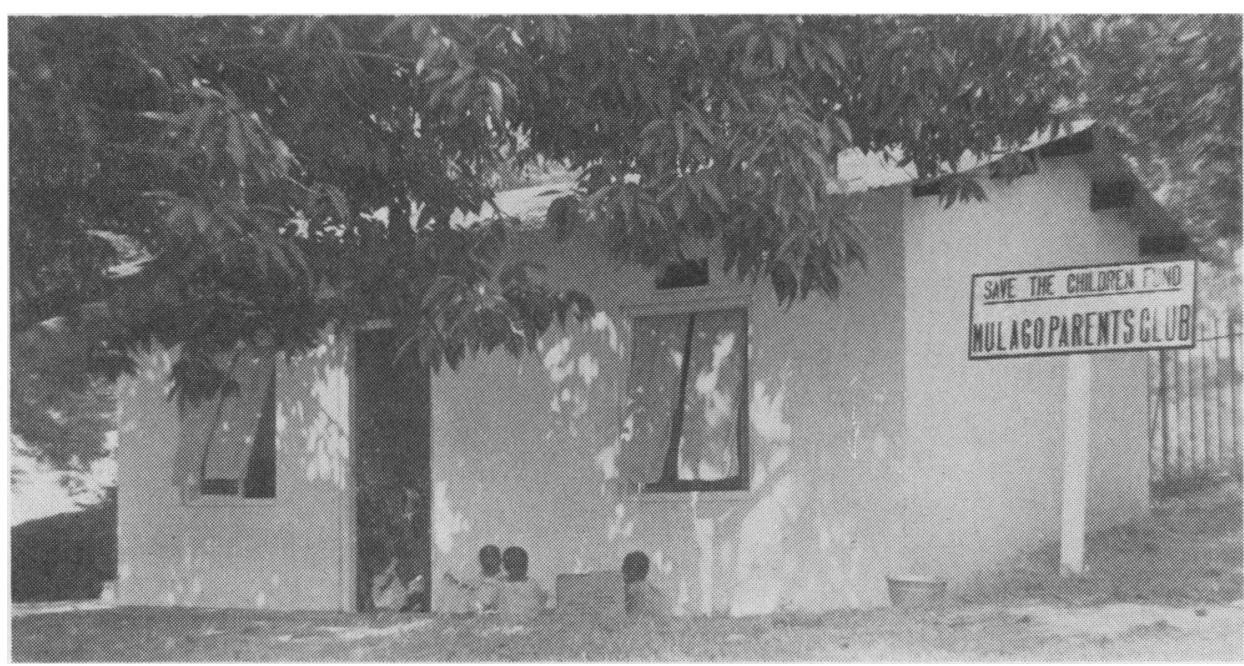

FIG. I.-Health education and clinical pædiatrics. Model low-cost house (£, 100$)$ adjacent to the pædiatric wards, Mulago Hospital, built with a grant from Save the Children Fund (Uganda). Used for the health education of parents.

rently they spend three months in the second clinical year in the Department of Pædiatrics and Child Health,* with a weekly lecture-demonstration running throughout this academic year. This is perhaps a not over-lavish period when related to the high percentage of the students' subsequent work which will concern children.

During their three months of pædiatric training teaching is carried on by such customary methods as case clerking, bedside teaching, ward rounds (including the newborn and premature), practical procedures, sleeping-in on emergency duty, and outpatient attendance. As, fortunately, mothers always come in with their children, preventive pædiatrics is also carried out adjacent to the ward by the department's health educator using a model house which has been built (Fig. I). In this students participate.

As Robinson (I96I) has very rightly emphasized, the traditional view that hospital beds are the most important, or sometimes the only, necessary facility for the teaching of pædiatrics is even more incorrect in economically less advanced countries, such as those of East Africa. So that, to counterbalance any over-emphasis towards institutional

\footnotetext{
* Pædiatrics has been taught as a separate major entity in the undergraduate curriculum for the last two and a half years. This development, initiated by the work of Dr. H. C. Trowell, has been greatly assisted by the ' Great Ormond Street Scheme', which has now been in successful operation for seven years to date. This consists of (i) the continuous secondment of a Senior Registrar and two Nursing Sisters from the Hospital for Sick Children, Great Ormond Street, for two-year periods and (ii) an annual one-month visit from a member of the consultant staff.
}

pædiatrics, the 'ivory hospital' approach (Cicely Williams, 1958), attention is also given to more preventive aspects of pædiatrics in the community by spending one afternoon weekly assisting in urban and rural child welfare clinics under the direction of Dr. Hebe Welbourn, and one morning each week visiting the homes of allotted families near Kasangati Health Centre, the rural training and demonstration area about nine miles from Kampala run by the Department of Preventive Medicine, where aspects of family health are observed and also the place of pædiatric activities in a defined community is brought into focus. Outside visits are made weekly to such social pædiatric activities as the School Feeding Programme, Community Development Women's Clubs, the Poliomyelitis Rehabilitation Centre and the Blind School.

Teaching safaris are an important local teaching device and are organized during most terms. In these a community child health survey is carried out in some part of East Africa by staff members assisted by pædiatric students (Fig. 2). This type of activity has the advantage that it combines field research with the production of information of practical value to the medical planner, while, at the same time, demonstrating to students the actuality of rural needs in East African pædiatrics (Galloway, 1961), as well as the use of field techniques, and the functions of categories of personnel not usually met in hospitals, such as health visitors. In fact, practical field experience in poor surroundings should form an integral part of training (Jelliffe, 1957a) (Fig. 3). Finally., a period shared in a tent in the bush can bé: an 


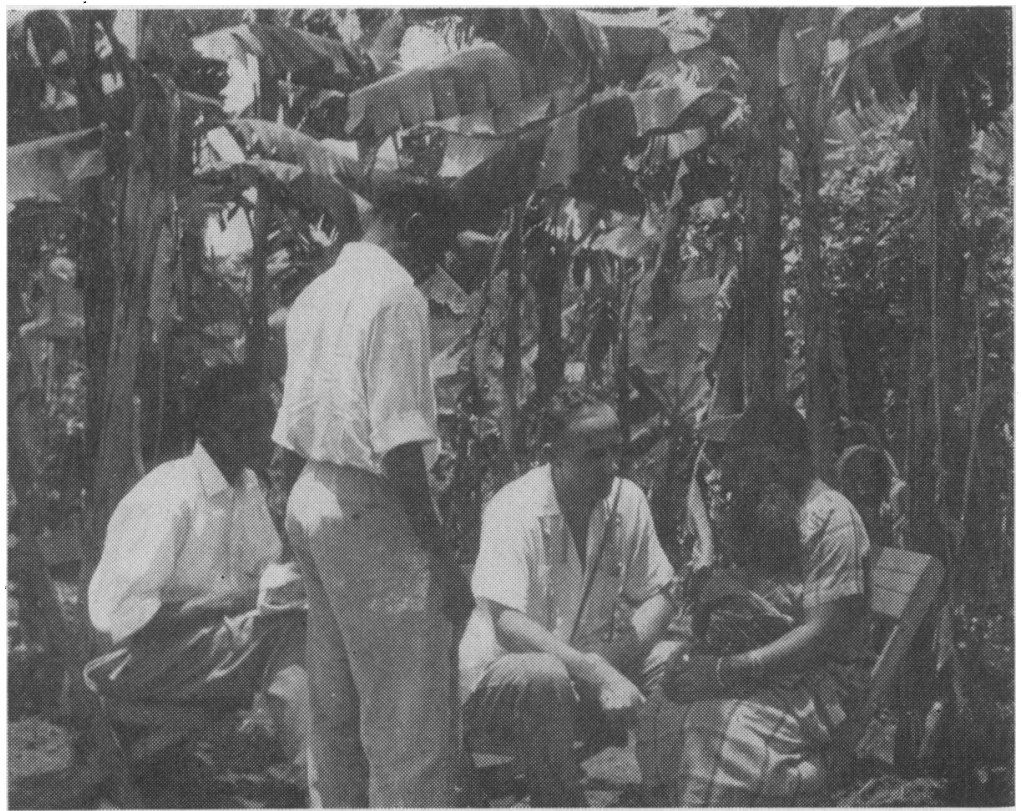

FIG. 2.-Adapted undergraduate teaching. Home visiting with students in Buganda.

excellent cementer of student-teacher relations.

All through the course of training every endeavour is made to insulate the student from an over-emphasis on the 'insect collector ', ' interesting rarity' approach. He is encouraged to realize that worthwhile research is needed in pædiatrics in East Africa into such simple-seeming and nongadget-ridden topics as local methods of child rearing, the changing pattern of breast-feeding, and, perhaps particularly, the most suitable practical ways of applying modern methods at the outpatient or village level.

\section{(2) Para-medical Personnel}

As part of the 'interim philosophy' previously mentioned, and with the present doctor population ratio in Uganda of approximately $I: 20,000$, it is apparent that the great bulk of practical curative and preventive child health work, both now and for decades to come, will have to be undertaken by such para-medical cadres as nurses, midwives, health visitors, community development workers and, above all, medical assistants. The correct training of these types of worker is then of great importance, and, in an attempt to assist the teachers in the various para-medical schools, a booklet is in the process of production covering the main.aspects of child health in the tropics (Jelliffe, rig62):

\section{(3) Postgraduate Training}

(i) Practitioners. As many medical practitionềंs (and, indeed, para-medical cadres) were traineक when pædiatrics received less emphasis than as present, it is very necessary to try to keep them abreast of relevant practical advances. In Easp Africa this is not easy for the usual reasons of shortage of finance and staff, and the long distance $\vec{B}$ involved and general difficulties with com 3 munications.

In Uganda this is, however, being attempted by a series of publications entitled 'Practical Notes 'O reprints of which are sent all over the region: (Jelliffe and Dean, I959; Jelliffe, I96rb; Jelliffe Rendle-Short, White and Trussell, I96I), by refresher courses and seminars held, so far, in Kampala, and by intermittent visiting safaris to hospitals in outlying districts. These have untip the present been limited by teaching staff and $b$ money, but, as a result of a further generous gran from UNICEF-WHO, it is intended that this most useful form of pædiatric training will beu stepped up by, for example, organizing refreshef courses in other parts of East Africa, sometimes af the district level, and by increasing the number and geographical scope of teaching safaris. To be effective the process has to be continuous.

(ii) Specialists. While the majority of child health work will continue to be undertaken by the general doctor, the nursing sister, the medicad 


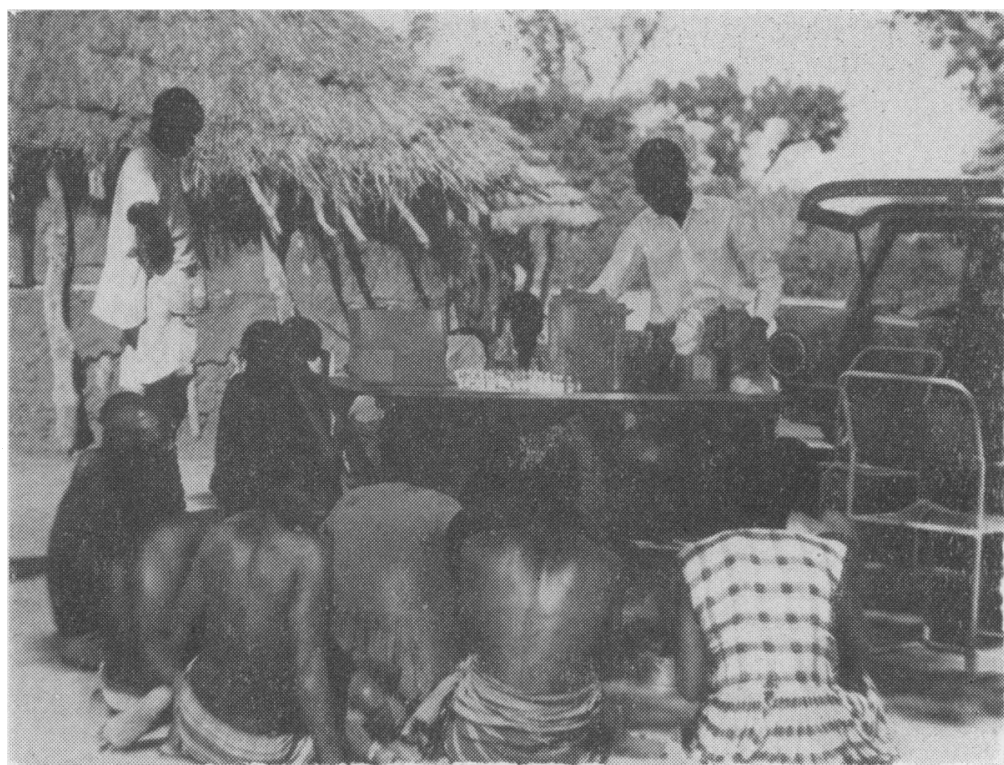

Fig. 3.-Teaching safari among the Lugbara, Arua, West Nile. Students collecting blood samples from young children.

assistant and others, there is also a need for a number of doctors and nurses with specialized knowledge to teach, to supervise, to advise and to act as leaders in this field.

The shortage of trained pædiatricians in East Africa at the time of writing may be judged by the following figures: Uganda 5, Tanganyika I, Kenya o, Zanzibar o. Although, of course, there are numerous practitioners in all three of the main ethnic groups of East Africa who deal with large numbers of children most proficiently, the generalization that the discipline of pædiatrics is least developed where most needed is certainly true (Robinson, 196r).

The need for qualified East African pædiatricians has to be, and is being, met, although the process must be a somewhat slow one. The best type of training is a blend of both overseas and local work and experience, and certainly should be both preventive and curative in emphasis, and definitely not exclusively clinical. It is best if the local part of the training can partly precede and partly follow the overseas portion.

\section{Problems of Overseas Pædiatric Training}

There are four main problems in relation to present-day possibilities for overseas training in pædiatrics and child health:

(i) Provision of Fellowships. This is the least difficult and can usually be readily met through an international foundation or agency, or from Commonwealth or U.S. sources.

(ii) Selection of Suitable Trainees. This always poses some problems, but with the present-day correct and understandable impetus towards Africanization it is necessary to train adequate candidates rather than wait for the ideal.

(iii) 'Sparability' in Medical Service. A major bottle-neck to higher medical training in underdoctored regions, such as East Africa, is that only a percentage of the medical staff can be permitted to go overseas at one time by the administration, as otherwise there would be a collapse of medical services. A too little explored manœuvre in this regard is that of trying to arrange for a 'substitute' to come from the United Kingdom or elsewhere to fill the gap while the trainee is away. This has been achieved in one instance in the Department of Pædiatrics.

(iv) Choice of Content and Location of Training. All students going for overseas training, from whatever region to whatever country, have mixed motives, including an anticipation of novelty and the excitement of living in an unknown part of the world. Indeed, it is good that this should be so, and if the stay is a happy one the benefits can be considerable on the trainees' general savoir faire and may perhaps help towards international amity.

However, from the professional point of view, there are two main considerations by which overseas training can be judged: firstly, the acquisition of technical knowledge and skill which will be of value to him in his own country, and, secondly, the acquisition of status in his chosen. subject, which will open up the way to professional, and hence 
financial, advancement for him, and which is partly related to the place and teachers with whom he has worked, but is more usually tied to specific symbols in the form of academic diplomas or degrees. In planning postgraduate training for aspirant pædiatricians from East Africa these two points require close scrutiny, and, it must be admitted, are matters of great difficulty, as there are no centres in the world which are really suitable.

In Britain the situation is made more difficult by the absence of a purely pædiatric postgraduate higher qualification. The African doctor anxious to work as a pædiatrician surrounded by the problems noted earlier has at present to spend considerable time learning adult clinical medicine of an almost completely different type from that found in his homeland in order to sit for one of the highly competitive Membership examinations, either in medicine alone or in medicine together with pædiatrics. While this may be correct training for the British pædiatrician, with the present shortages and extreme pressures in the tropics, it represents a delay and a complexity which appears, at least, to be unfortunate. One wonders whether the present-day reappraisal of education and of formal qualifications may not lead to the evolution by internal rearrangement of the structure of the current examinations, so that they might be taken in pædiatrics alone.

Only too often, partly because of examination orientation, even the pædiatric training received overseas is not as suitable as it might be, so that, apart from excellent instruction in the general practice and philosophy of the subject, there may be an over-emphasis on conditions of no tropical significance, such as fibrocystic disease, and on elaborate scientific investigational techniques, which can (and often does) cause a feeling of confusion and futility when the trainee returns home. In fact, it may be restated that the practice of sending young physicians to postgraduate pædiatric centres in Europe or America may sometimes do more harm than good, as the advanced technical knowledge acquired may be almost completely inapplicable in the home country and may merely frustrate-so that he thinks in terms of batteries of biochemical tests and EEG examinations when facilities for these are quite lacking, and, indeed, gas and electricity may not always be readily available (Jelliffe, 1955b). At the same time, there is usually little or no consideration given to the realities of tropical pædiatrics, such as proteincalorie malnutrition and locally meaningful infant feeding, intestinal helminth infections and malaria, cross-cultural problems, and an understanding of the need for a community epidemiological approach (Fig. 4).

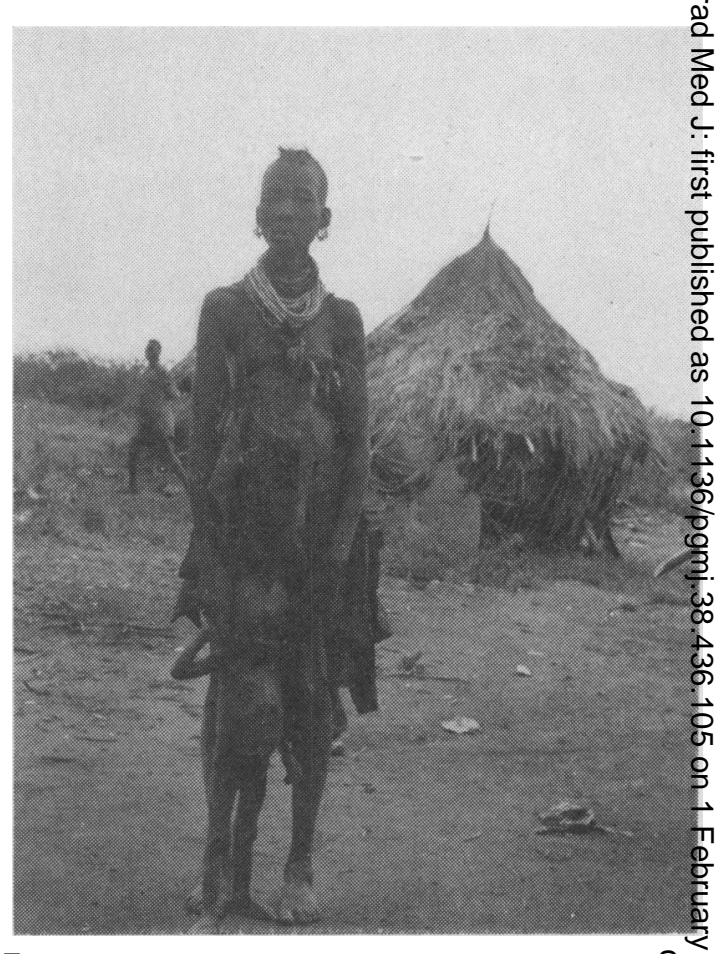

FIG. 4.--Reality in tropical pædiatrics. Drought: famine, poverty, poor hygiene and a further peg nancy leading to protein-calorie malnutrition in pre-school age child in Karamoja, the least 'developed' part of Uganda.

An exclusively clinical pædiatrician in the developing tropical countries is, in effect, one-eyed and incomplete. It is absolutely necessary for him to be both a curative and preventive worker at the same time. Overseas training, therefore, must ideally have its clinical component balanced by public health training, provided (as is not usually the case) this can include selective emphasis og maternal and child health $(\mathrm{MCH})$, health education, nutrition, sociology and epidemiology.

In the U.S.A. the last can be achieved by the M.P.H. course, which in at least several leading American schools of public health can be taken with $\mathrm{MCH}$ as a major subject. However, problems arise in 'clinical' pædiatrics from the point of view of the time intervals needed to produce pædiatricians for East Africa in that prolongee residency requirements are needed before the boards examination of the American Academy off Pædiatrics can be taken. It may be noted that equation of U.K. and U.S.A. specialist qualificas tions, always a difficult matter, is almost certain to be attempted, either before or after independence. of the East African territories.

In conclusion, the following general type of scheme appears to be best suited for the post足 
graduate training of doctors from East African and other developing tropical regions as specialist child health workers:

(i) A period of at least one year as pædiatric registrar or similar post under adequate supervision in his homeland (with experience in various aspects of the subject, including the newborn and prematures and also with a portion of his work related to preventive pædiatrics, such as child welfare clinics and other social health activities).

(ii) A period of at least one year at a suitable pædiatric centre overseas, learning general ' cosmopolitan' pædiatrics, with, if possible, some systematic instruction in tropical pædiatric problems and with half of the time spent on 'in-service' training, preferably leading to a 'status-giving' examination in padiatrics.

(iii) A period of one academic year, usually nine months, taking the course leading to a recognized public health diploma, in which $\mathrm{MCH}$, health education, nutrition, sociology, epidemiology and 'tropical medicine' should be considerable subjects.

(iv) A period of three months spent visiting relevant leading tropical centres (as, for example, in the Caribbean-University College of the West Indies, Institute of Nutrition of Central America and Panama, University of Puerto Rico).

(v) A 'guided readjustment' period of six to 12 months, or longer, at the original centre in the homeland, followed by continual personal training, as it is with experience, above all, that real knowledge of the subject is gradually achieved.

This type of schedule tries to achieve a balance between curative and preventive pædiatrics, between clinical and public health emphases, between tropical and 'cosmopolitan' pædiatrics, and between didactic teaching, in-service training and observation. It would undoubtedly produce a very suitable person in the shortest space of time. Perhaps in the future some scheme of this sort may become practicable. There is none at the moment and it is certainly needed.

\section{Acknowledgments}

I would like to thank Dr. F. J. Bennett and Dr. C. J. Lewthwaite for permission to use certain of their photographs.

\section{REFERENCES}

Davies, J. N. P. (1955): Children's Diseases at Mulago Hospital, 1950-5I: An Analysis of the Causes of Admission, East Afr. med. Э., 32, 283.

Galloway, A. (1961): The Growth of Medical Education in East Africa, F. med. Educat., 36, 305 .

JellifFe, D. B. (1955a): Infant Nutrition in the Subtropics and Tropics, Wld Hlth Org. Monogr. Ser. 29.

- (1955b): Pediatric Education in Relation to Child Health in Subtropical and Tropical Regions, Pediatrics, 16, 398.

- (1957a): Maternal and Child Health in Technically Developing Countries, Bull. Tulane med. Fac., 16, 55.

- (1957b): Cultural Blocks and Protein Malnutrition in Early Childhood in Rural West Mengal, Pediatrics, $20,128$.

(1959): Protein-Calorie Malnutrition in Tropical Pre-school Children, F. Pediat., 5, 96.

- (196ra): Culture, Social Change and Infant Feeding, Amer. F. clin. Nutr. (in press).

(editor) (I96rb): 'Child Health in the Tropics'. London: Edw. Arnold (in press).

- (196rc): Diarrhoal Disease in Early Childhood in Tropical Regions: Practical Notes, f. trop. Pediat., 7, 29. , and Bennetr, F. J. (1960): Indigenous Medical Systems and Child Health, $\mathcal{F}$. Pediat., 57, 248.

(1961): World-wide Care of the Mother and Newborn Child: Section in Symposium on the Newborn (edited M. Newton), Clin. Obstet. Gynacol. (in press).

, - STroud, E. C., Novotny, N., Karrach, K., Musoke, L. K., and Jelliffe, E. F. P. (1961): Field Survey of the Health of Bachiga Children in the Kayonza District of Kigezi, Uganda, Amer. F. trop. Med. Hyg., 10, 435. 5, and DEAN, R. F. A. (1959): Protein-Calorie Malnutrition in Early Childhood: Practical Notes, F. trop. Pediat.,

Hyg. (in press), C., White, R. H. R., and Trussell, R. (196r): The Routine Care of the Premature, Y. trop. Med. Hyg. (in press).

Musoke, L. K. (1961): An Analysis of Admissions to the Pædiatric Division, Mulago Hospital in 1959, Arch. Dis. Childh., 36, 305.

Robinson, P. (I96r): Undergraduate Pædiatric Education in South-East Asia, Acta padiat. (Uppsala), $50,329$.

Welbourn, H. F. (1958): Bottle-feeding: A Problem of Civilization, F. trop. Pediat., 3, 157.

Williams, C. D. (1955): The Organization of Child Health Services in Developing Countries, Ibid., I, 3.

(1958): Social Medicine in Developing Countries, Lancet, i, 863. 